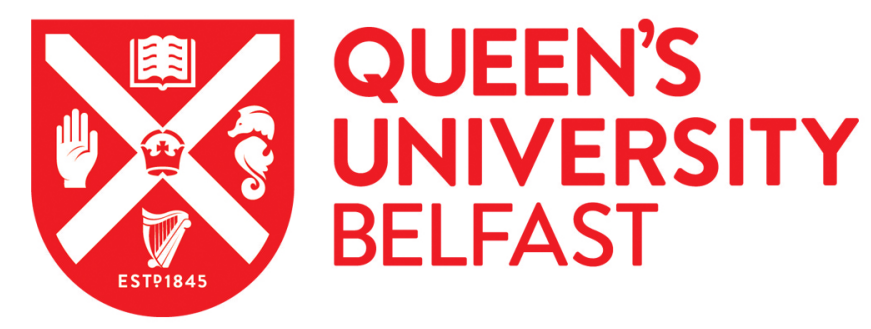

\title{
Domestic Violence and the Inter-American Commission on Human Rights: Jessica Lenahan (Gonzales) v United States
}

\author{
McQuigg, R. J. A. (2012). Domestic Violence and the Inter-American Commission on Human Rights: Jessica \\ Lenahan (Gonzales) v United States. Human Rights Law Review, 12 (1)(1), 122-134. [ngr044]. \\ https://doi.org/10.1093/hrlr/ngr044
}

\section{Published in:}

Human Rights Law Review

\section{Document Version:}

Early version, also known as pre-print

Queen's University Belfast - Research Portal:

Link to publication record in Queen's University Belfast Research Portal

Publisher rights

(C) The Author [2012]. Published by Oxford University Press. This work is made available online in accordance with the publisher's policies. Please refer to any applicable terms of use of the publisher.

\section{General rights}

Copyright for the publications made accessible via the Queen's University Belfast Research Portal is retained by the author(s) and / or other copyright owners and it is a condition of accessing these publications that users recognise and abide by the legal requirements associated with these rights.

Take down policy

The Research Portal is Queen's institutional repository that provides access to Queen's research output. Every effort has been made to ensure that content in the Research Portal does not infringe any person's rights, or applicable UK laws. If you discover content in the Research Portal that you believe breaches copyright or violates any law, please contact openaccess@qub.ac.uk. 


\title{
Domestic Violence and the Inter-American Commission on Human Rights: Jessica Lenahan (Gonzales) v United States.
}

\author{
Dr. Ronagh J.A. McQuigg.*
}

This is a pre-copy-editing, author-produced PDF of an article accepted for publication in Human Rights Law Review following peer review. The definitive publisher-authenticated version [(2012) 12 Human Rights Law Review 122-134] is available online at http://hrlr.oxfordjournals.org/content/12/1/122

On 21 July 2011 the Inter-American Commission on Human Rights issued its much awaited decision in the case of Jessica Lenahan (Gonzales) $v$ United States. ${ }^{1}$ In a landmark judgment the Commission found the United States of America to be in violation of the American Declaration of the Rights and Duties of Man 1948 due to the failure of the state to protect a victim of domestic violence and her children. This paper seeks to analyse the Lenahan decision and its significance for the United States. In particular, the substantial influence of the case law of the European Court of Human Rights on the Commission's reasoning will be examined.

\section{The Facts of the Case}

The case arose from a petition presented to the Inter-American Commission on Human Rights against the Government of the United States of America by representatives of the American Civil Liberties Union. The petition was presented on behalf of Jessica Lenahan, formerly Jessica Gonzales, and her three deceased daughters. The claimants argued that the United States had violated a number of provisions of the American Declaration of the Rights and Duties of Man, due to a failure to exercise due diligence in protecting Jessica Lenahan and her daughters from acts of domestic violence on the part of Ms Lenahan's former husband (Simon Gonzales). It was claimed that the police had failed to respond in an adequate manner to Ms Lenahan's repeated and urgent telephone calls reporting that her husband had taken their three daughters, who were aged seven, eight and ten, in violation of a domestic violence restraining order held by Ms Lenahan. Simon Gonzales had eventually arrived at the police station and opened fire at police. The police returned fire, resulting in his death. The three children were later found shot to death in the back of their father's truck. The petitioners claimed that the state had never duly investigated the circumstances of the deaths of the children, and had never

\footnotetext{
* Lecturer, School of Law, Queen's University Belfast. Email: r.mcquigg@qub.ac.uk

${ }^{1}$ Case 12.626, Report No. 80/11 (2011).
} 
provided Ms Lenahan with a sufficient remedy for the failures of the police. It was argued that these circumstances amounted to violations of a number of provisions of the American Declaration of the Rights and Duties of Man, including Article I (the right to life), Article II (the right to equality), Article VII (relating to the special protection of children), and Article XVIII (the right to judicial protection).

The state, on the other hand, argued that the authorities had responded as they were required to do by law. Moreover, it claimed that the petitioners had cited no provision of the American Declaration that imposed on the state an affirmative duty to prevent the commission of individual crimes by private actors. Nevertheless, the InterAmerican Commission held that the United States had failed to act with due diligence to protect Ms Lenahan and her three daughters from domestic violence, in breach of Articles I, II, VII and XVIII of the American Declaration.

\section{The Commission's Reasoning}

\section{A. The Right to Equality}

Article II of the American Declaration states that, "All persons are equal before the law and have the rights and duties established in this Declaration, without distinction as to race, sex, language, creed or any other factor.' The petitioners argued that discrimination in violation of Article II was 'the common thread' in all of the state's failures to guarantee the rights of Ms Lenahan and her daughters. ${ }^{2}$ They claimed that the state's failure to respond adequately to Ms Lenahan's telephone calls regarding the disappearance of her daughters, its failure to conduct an investigation into the children's deaths, and its failure to offer Ms Lenahan an appropriate remedy as regards the lack of enforcement of the restraining order, all constituted acts of discrimination in violation of Article II.

In its judgment, the Commission commented that, 'The principle of nondiscrimination is the backbone of the universal and regional systems for the protection of human rights. ${ }^{3}$ In ensuring this principle,

States are not only obligated to provide for equal protection of the law. They must also adopt the legislative, policy and other measures necessary to guarantee the effective enjoyment of the rights protected under Article II...In practice this means that States have the obligation to adopt the measures necessary to recognize and guarantee the effective equality of all persons before the law; to

\footnotetext{
${ }^{2}$ Ibid. at para 105.

${ }^{3}$ Ibid. at para 107.
} 
abstain from introducing in their legal framework regulations that are discriminatory towards certain groups either in their face or in practice; and to combat discriminatory practices. ${ }^{4}$

In applying these obligations to the area of violence against women, the Commission stated that, 'Gender-based violence is one of the most extreme and pervasive forms of discrimination, severely impairing and nullifying the enforcement of women's rights. ${ }^{5}$ It proceeded to assert that, 'The obligations established in Article II extend to the prevention and eradication of violence against women, as a crucial component of the State's duty to eliminate both direct and indirect forms of discrimination. In accordance with this duty, State responsibility may be incurred for failures to protect women from domestic violence perpetrated by private actors in certain circumstances. ${ }^{6}$ The Commission was of the view that the United States had failed to fulfil their obligations under Article II as regards the situation in question, and therefore found a violation in respect of this provision.

\section{B. The Right to Life}

Article I of the American Declaration states that, 'Every human being has the right to life, liberty and the security of his person.' The Commission commented that, 'Various international human rights bodies have moreover considered State failures in the realm of domestic violence not only discriminatory, but also violations of the right to life of women. ${ }^{7}$ It stated that, "The right to life is one of the core rights protected by the American Declaration which has undoubtedly attained the status of customary international law. ${ }^{8}$ The Commission was of the view that,

The protection of the right to life is a critical component of a State's due diligence obligation to protect women from acts of violence. This legal obligation pertains to the entire state institution, including the actions of those entrusted with safeguarding the security of the State, such as the police forces. It also extends to the obligations a State may have to prevent and respond to the actions of non-state actors and private persons. ${ }^{9}$

\footnotetext{
${ }^{4}$ Ibid. at paras 108-109.

${ }^{5}$ Ibid. at para 110.

${ }^{6}$ Ibid. at para 120.

${ }^{7}$ Ibid. at para 112.

${ }^{8}$ Ibid. at para 112.

${ }^{9}$ Ibid. at para 128.
} 
The Commission held that the state had failed to take reasonable measures to protect the lives of Ms Lenahan's three daughters, and that this failure therefore constituted a violation of their right to life, as contained in Article I of the American Declaration.

\section{The Right of Children to Special Protection}

Article VII of the American Declaration provides that, 'All women, during pregnancy and the nursing period, and all children, have the right to special protection, care and aid.' In applying this provision to the area of domestic violence, the Commission stated that, 'Protection measures are considered particularly critical in the case of girlchildren... since they may be at a greater risk of human rights violations based on two factors, their sex and age. ${ }^{10}$ Again, the Commission held that the state had failed to provide adequate protection measures to the three children in question, and that this failure constituted a violation of Article VII.

\section{The Right to Judicial Protection}

Article XVIII of the American Declaration provides that, 'Every person may resort to the courts to ensure respect for his legal rights. There should likewise be available to him a simple, brief procedure whereby the courts will protect him from acts of authority that, to his prejudice, violate any fundamental constitutional rights.' The Commission stated that there had been a failure on the part of the state to undertake a proper inquiry into the nonenforcement of the domestic violence protection order which had been in place against Ms Lenahan's former husband. In addition, the state had failed to perform a prompt, thorough and impartial investigation into the deaths of her three daughters, and had failed to convey information to the family relevant to the circumstances of their deaths. There had thus been a violation of Article XVIII also.

\section{The Commission's Recommendations}

The Commission concluded its decision by making a series of wide-ranging recommendations to the United States. These included that the state should undertake an impartial and exhaustive investigation into the deaths of Ms Lenahan's daughters. It should also conduct an investigation into the failures relating to the enforcement of the protection order, with the aim of ensuring that such failures would not re-occur. An inquiry should be carried out with the aim of holding those responsible to account. In addition, full reparations should be offered to Ms Lenahan.

\footnotetext{
${ }^{10}$ Ibid. at para 113.
} 
At a broader level, the Commission asserted that it was necessary for the United States to 'adopt multifaceted legislation at the federal and state levels, or reform existing legislation, including protection measures for children in the context of domestic violence. ${ }^{11}$ The Commission stated that these measures should be accompanied by adequate resources to foster their implementation; regulations to ensure their enforcement; training programmes for the law enforcement officials who would be involved in their execution; and the design of model directives to be followed by police departments. The state should also adopt legislation, or reform existing legislation, with the aim of ensuring the protection of children in the context of domestic violence. In addition, the Commission recommended that the United States,

Continue adopting public policies and institutional programs aimed at restructuring the stereotypes of domestic violence victims, and to promote the eradication of discriminatory socio-cultural patterns that impede women and children's full protection from domestic violence acts, including programs to train public officials in all branches of the administration of justice and police, and comprehensive prevention programs. ${ }^{12}$

Finally, it was recommended that the state design protocols specifying the proper components of how an investigation of a report of missing children in the context of a violation of a restraining order should be carried out.

\section{The Influence of the Case Law of the European Court of Human Rights}

In its decision in this case the Inter-American Commission referred extensively to the jurisprudence of the European Court of Human Rights on the issue of domestic violence. Until 2007 domestic violence had not been directly addressed substantively by the European Court, however in the past four years the Court has directly addressed this issue in a series of cases. These include Kontrova $v$ Slovakia $;{ }^{13}$ Bevacqua and $S$ v Bulgaria ${ }^{14}$ Branko Tomasic and Others v Croatia $;{ }^{15}$ Opuz v Turkey; ${ }^{16}$ E.S. and Others $v$ Slovakia ${ }^{17}$ and $A v$ Croatia. $^{18}$ In the Lenahan case the Inter-American Commission stated that the

${ }^{11}$ Ibid. at para 215.

${ }^{12}$ Ibid. at para 215.

${ }^{13}$ Application No 7510/04, Merits, 24 September 2007.

${ }^{14}$ Application No 71127/01, Merits, 12 September 2008.

${ }^{15}$ Application No 46598/06, Merits, 15 January 2009.

${ }^{16}$ Application No 33401/02, Merits, 9 September 2009.

${ }^{17}$ Application No 8227/04, Merits, 15 December 2009.

${ }^{18}$ Application No 55164/08, Merits, 14 October 2010. 
European Court has, in its jurisprudence, 'advanced important principles related to the scope and content of the State's obligation to prevent acts of domestic violence. ${ }^{\prime 19}$ The Commission proceeded to comment that,

The European Court has considered the obligation to protect as one of reasonable means, and not results, holding the State responsible when it failed to take reasonable measures that had a real prospect of altering the outcome or mitigating the harm. The Court has established that authorities should consider the prevalence of domestic violence, its hidden nature and the casualties of this phenomenon in the adoption of protection measures; an obligation which may be applicable even in cases where victims have withdrawn their complaints. Given the nature of domestic violence, under certain circumstances authorities may have reason to know that the withdrawal of a complaint may signify a situation of threats on the part of the aggressor, or the State may at a minimum be required to investigate that possibility. Lastly, the Court has ruled that a State's failure to protect women from domestic violence breaches their right to equal protection of the law and that this failure does not need to be intentional. ${ }^{20}$

In its reasoning, the Inter-American Commission referred in particular to the European Court's decisions in Kontrova v Slovakia, ${ }^{21}$ Opuz $v$ Turkey ${ }^{22}$ and Branko Tomasic and Others $v$ Croatia. ${ }^{23}$ In Kontrova $v$ Slovakia the applicant had been subjected to domestic violence by her husband. He had threatened to kill himself and their two children and he had in fact carried out this threat. There were thus very clear similarities between the facts of this case and those of the Lenahan case. The applicant in Kontrova alleged that the police had failed to take appropriate action to protect her children's lives under Article 2 of the European Convention on Human Rights 1950, and her own private and family life under Article 8 of the Convention, despite knowing of her husband's abusive behaviour. Under domestic law in Slovakia, the police had various specific obligations, such as accepting and registering the applicant's complaint; launching a criminal investigation; and commencing proceedings against the applicant's husband immediately. However, they had failed to comply with any of these obligations.

\footnotetext{
${ }^{19}$ Supra n 1 at para 134.

${ }^{20}$ Ibid. at para 134.

${ }^{21}$ Supra n 13.

${ }^{22}$ Supra n 16.

${ }^{23}$ Supra n 15.
} 
In holding that there had been a breach of the children's right to life, the Court stated that Article 2, 'enjoins the State not only to refrain from the intentional and unlawful taking of life, but also to take appropriate steps to safeguard the lives of those within its jurisdiction...It also extends in appropriate circumstances to a positive obligation on the authorities to take preventive operational measures to protect an individual whose life is at risk from the criminal acts of another individual. ${ }^{24}$ The applicant alleged that the violation of Article 2 also constituted a violation of her own private and family life under Article 8, however the Court held that in the light of the finding of a violation of Article 2, it was not necessary to examine the case under Article 8 also.

Opuz v Turkey ${ }^{25}$ was another case from the European Court which bore similarities to the facts of the Lenahan case, in that both cases concerned victims of domestic violence who had family members who had been killed by the perpetrators. In Opuz both the applicant and the applicant's mother had been subjected to violence on the part of the applicant's husband. The applicant alleged that the authorities had failed to protect herself and her mother from domestic violence, which had resulted in the death of her mother and her own ill-treatment. She complained that the authorities had failed to safeguard the right to life of her mother in violation of Article 2 of the Convention. The Court concluded that 'The criminal law system, as applied in the instant case, did not have an adequate deterrent effect capable of ensuring the effective prevention of the unlawful acts committed by (the applicant's husband). ${ }^{26}$ There had thus been a breach of Article 2.

The applicant also argued that there had been a violation of Article 3 of the Convention, which contains the right to be free from torture or inhuman or degrading treatment. She alleged that she had been subjected to violence, injury and death threats but that the authorities had been negligent towards her situation, which caused her pain and fear in breach of Article 3. The Court concluded that there had indeed been a violation of Article 3 'as a result of the State authorities' failure to take protective measures in the form of effective deterrence against serious breaches of the applicant's personal integrity by her husband. ${ }^{27}$

\footnotetext{
${ }^{24}$ Supra n 13 at para 49.

${ }^{25}$ Supra n 16.

${ }^{26}$ Ibid. at para 153.

${ }^{27}$ Ibid. at para 176.
} 
In addition, the applicant claimed that there had been a breach of Article 14 of the Convention, the prohibition of discrimination, an argument which was also upheld by the Court. The applicant demonstrated through statistical data that domestic violence affected mainly women, and established that judicial passivity in Turkey created a climate conducive to domestic violence. It was stated that, 'Bearing in mind...that the general and discriminatory judicial passivity in Turkey, albeit unintentional, mainly affected women, the Court considers that the violence suffered by the applicant and her mother may be regarded as gender-based violence which is a form of discrimination against women. ${ }^{28}$ Such an approach was also followed by the Inter-American Commission in its decision in the Lenahan case. In its decision the Commission clearly stated that, "The principle of non-discrimination is the backbone of the universal and regional systems for the protection of human rights. ${ }^{29}$ In finding a violation of Article II of the American Declaration, the Commission was forceful in its view that, 'Genderbased violence is one of the most extreme and pervasive forms of discrimination, severely impairing and nullifying the enforcement of women's rights. ${ }^{30}$ It seems that the approach of the European Court on the application of the principle of nondiscrimination to gender-based violence clearly influenced the Inter-American Commission's reasoning in the Lenahan case.

The Inter-American Commission also referred to the case of Branko Tomasic and Others $v$ Croatia $^{31}$ from the European Court. In this case the applicants were relatives of a victim of domestic violence who had been shot dead, along with her daughter, by her former partner who had then committed suicide. The perpetrator had previously been found guilty by a Croatian court of repeatedly threatening that he would kill himself, his former partner and their child with a bomb. He was sentenced to five months' imprisonment and was ordered to have compulsory psychiatric treatment during his imprisonment and afterwards as necessary. An appeal court later reduced the treatment to the duration of his sentence. One month after his release he killed himself, his former partner and their child. The applicants argued that there had been violations of the right to life under Article 2 of the European Convention and the right to an effective remedy under Article 13 of the Convention. The basis of the complaints was that the state had failed to take sufficient measures to protect the victims, and had also failed to conduct an effective investigation into the possible responsibility of the state for the deaths.

\footnotetext{
${ }^{28}$ Ibid. at para 200.

${ }^{29}$ Supra $\mathrm{n} 1$ at para 107.

${ }^{30}$ Supra $\mathrm{n} 1$ at para 110.

${ }^{31}$ Supra n 15.
} 
The European Court held that there had indeed been a breach of Article 2. No search of the perpetrator's premises and vehicle had been carried out during the initial criminal proceedings, despite the fact that he had repeatedly threatened to use a bomb. In addition, although a psychiatric report which had been drawn up for the purposes of the criminal proceedings had emphasised the need for continued psychiatric treatment, the state had failed to ensure that the perpetrator had indeed been properly treated. In fact, he had not followed an individual programme during the prison term despite this being required by law. Also, he had not been examined immediately prior to his release from prison in order to assess whether he had posed a risk to the victims. Interestingly, having found that there had been a violation of Article 2 due to the failure of the state to take sufficient measures to protect the victims, the Court held that there was no need to examine separately the complaint that the state had failed to undertake a thorough investigation into the possible responsibility of its agents for the deaths of the victims. It could perhaps be argued that it would have been preferable if the Court had examined this complaint also, for the sake of completeness. However, it is the European Court's common practice, having found a violation in one aspect of a case, to omit to examine arguments concerning other aspects of the situation in question. Similarly, in Branko Tomasic the Court also held that, having found a violation of Article 2, there was no need to examine the complaint under Article 13.

If the European Court in Branko Tomasic had examined the aspect of the case surrounding the lack of an effective investigation, this would have made the case even more pertinent to the Inter-American Commission's decision in Lenahan. However, the European Court has certainly developed jurisprudence on the procedural aspect of the right to life in many other cases. ${ }^{32}$ In the Lenahan case, the Inter-American Commission held that the state had failed to perform a prompt, thorough and impartial investigation into the deaths of the three children, and had failed to convey information to the family relevant to the circumstances of their deaths. However, it is notable that this part of the case was examined in relation to Article XVIII of the American Declaration on the right to judicial protection, as opposed to Article I on the right to life. It could certainly be argued, as in Branko Tomasic, that the state may have borne some responsibility for the deaths in question in the Lenahan case, due to the failure of the police to respond adequately to Ms Lenahan's requests for help. If the European Court in Branko Tomasic had examined the complaint regarding the lack of an effective investigation into the deaths in that case, it is possible that the Inter-American Commission may well have followed suit in Lenahan and analysed the lack of a sufficient investigation as a violation of the procedural aspect of the right to life also.

\footnotetext{
${ }^{32}$ For example, Hugh Jordan v United Kingdom (Application No 24746/94, Merits, 4 May 2001); Kelly and Others v. United Kingdom (Application No 30055/96, Merits, 4 May 2001); McKerr v United Kingdom (Application No 28883/95, Merits, 4 May 2001); Shanaghan v United Kingdom (Application No 37715/97, Merits, 4 May 2001).
} 


\section{The Lenahan Case in the Context of United States Jurisprudence on Positive Duties}

The decision of the Inter-American Commission in Lenahan is particularly significant given the strong opposition of the United States Supreme Court to the placing of positive duties on the state to protect individuals from the criminal acts of other individuals. The seminal case in this area is the well-known decision of the Supreme Court in DeShaney $v$ Winnebago County Department of Social Services. ${ }^{33}$ In this case, the petitioner was a child who had been subjected to a series of beatings by his father. The Department of Social Services had received complaints that the petitioner was being abused by his father, however although they took various steps to protect the petitioner, they did not remove him from his father's custody. The petitioner's father finally beat him so severely that he suffered permanent brain damage. The petitioner and his mother argued that the respondents had deprived the petitioner of his liberty interest in bodily integrity, in violation of his rights under the Due Process Clause of the Fourteenth Amendment to the U.S. Constitution, by failing to intervene to protect him from his father's violence. The Due Process Clause states that no state shall 'deprive any person of life, liberty, or property, without due process of law.' The Supreme Court held that the respondents' failure to provide the petitioner with sufficient protection did not violate his rights under the Due Process Clause.

The Supreme Court was of the opinion that the Clause imposed no duty on the state to provide members of the general public with adequate protective services. According to the Court, although the Clause forbade the state itself from depriving individuals of life, liberty, and property without due process of law, it did not impose a positive obligation on the state to ensure that those interests did not come to harm through other means. The petitioner had argued that the state's knowledge of his danger and expressions of willingness to protect him against that danger had established a 'special relationship' giving rise to an affirmative constitutional duty to protect. However, the Court held that such a 'special relationship' could arise only from limitations which the state itself had imposed on an individual's freedom to act on his own behalf, for example through imprisonment. The Due Process Clause did not therefore impose a positive duty on the state to provide the petitioner with sufficient protection.

In relation to the issue of domestic violence, the impact of such reasoning was expressed succinctly in a recent report by the United Nations Special Rapporteur on violence against women, its causes and consequences. According to the Special

33489 U.S. 189, 22 February 1989. 
Rapporteur, 'The effect of cases such as DeShaney...is that even where local and state police are grossly negligent in their duties to protect women's right to physical security, and even where they fail to respond to an urgent call of assistance from victims of domestic violence, there is no constitutional or statutory remedy at the federal level. ${ }^{34}$ The fact that the Inter-American Commission on Human Rights has now found the United States to be in violation of several provisions of the American Declaration for its failure to provide adequate protection to a victim of domestic violence and her children is therefore of immense significance. The obvious question that now arises is whether the United States will respond in a positive manner to this finding. Unfortunately it is doubtful whether this will prove to be the case. Prior to issuing its decision in Lenahan the Inter-American Commission sent a report on the merits of the case to the United States in order for the latter to report on its compliance with the recommendations issued. However, no response was received within the time period provided. In its decision in Lenahan the Commission stated that, 'Given the lack of information from the State, the Commission must conclude that the recommendations issued have not been implemented, and that their compliance thus remains pending. The Commission is accordingly required to reiterate those recommendations and continue monitoring compliance. ${ }^{35}$ It remains to be seen whether the United States will yet respond in a positive manner to the decision.

The question of whether compliance will indeed occur is however somewhat debatable. One of the primary problems with ensuring the effectiveness of international human rights law is the fact that it can be very difficult to compel states to comply with their duties. As Byrnes comments, 'The limitations of international law generally when it comes to enforcement of binding standards are well known, and international human rights law is no exception in that regard. ${ }^{36}$ Merry states that, 'Countries are concerned about their reputations in the international community, but they clearly differ in their vulnerability to international pressure depending on their size, wealth, form of government, and dependence on the international community for trade, aid, and other symbolic and material forms of exchange. ${ }^{37}$ The United States is a case in point. The

\footnotetext{
${ }^{34}$ Statement from Special Rapporteur on violence against women, its causes and consequences, at the conclusion of her fact finding mission to the United States of America, 8 February 2011, available at http://www.ohchr.org/en/NewsEvents/Pages/DisplayNews.aspx?NewsID=10715\&LangID=E [last accessed 31 October 2011].

${ }^{35}$ Supra n 1 at para 207.

${ }^{36}$ Byrnes, 'Enforcement Through International Law and Procedures' in Cook (ed), Human Rights of Women - National and International Perspectives (Philadelphia: University of Pennsylvania Press, 1994) 189 at $191-192$.

${ }^{37}$ Merry, 'Constructing a Global Law - Violence against Women and the Human Rights System' (2003) 28 Law and Social Inquiry 941 at 959.
} 
most powerful nation in the world has not ratified the United Nations Convention on the Elimination of All Forms of Discrimination against Women $1979^{38}$ or the United Nations Convention on the Rights of the Child $1989,{ }^{39}$ and tends to ratify other international human rights treaties only with extensive reservations.

One of the treaties which have been ratified by the United States is the International Covenant on Civil and Political Rights $1966 .{ }^{40}$ The compliance of the United States with its obligations under this treaty was most recently considered by the Human Rights Committee in 2006. One of the recurring themes of the Committee's Concluding Observations on the report of the United States was the failure of the State party to comply with its positive obligations under the treaty. The Committee noted with concern, 'the restrictive interpretation made by the State party of its obligations under the Covenant'. ${ }^{41}$ According to the Committee, one of the main difficulties in this regard was the failure of the United States 'to take fully into consideration its obligation under the Covenant not only to respect, but also to ensure the rights prescribed by the Covenant ${ }^{\prime 2}$. The Committee recommended that the State party 'take positive steps, when necessary, to ensure the full implementation of all rights prescribed by the Covenant.' 43 It seems therefore that the reluctance of the United States Supreme Court to place positive duties on the state to protect individuals from the criminal acts of other individuals is symptomatic of a wider failure on the part of the United States to comply with its positive obligations under international human rights law.

\section{Conclusion}

In conclusion therefore, the decision of the Inter-American Commission in Lenahan is certainly a very significant development as regards the application of human rights law to the issue of domestic violence. In analysing the importance of this decision it must be remembered that until relatively recently domestic violence was not even viewed as a human rights issue. Human rights law was originally developed in such a way as to create a public / private dichotomy, whereby human rights norms were applied in the

\footnotetext{
381249 UNTS 13.

391577 UNTS 3.

40999 UNTS 171.

${ }^{41}$ Human Rights Committee, Concluding Observations regarding United States of America, 18 December 2006, CCPR/C/USA/CO/C/Rev.1, at para 10.

${ }^{42}$ Ibid. at para 10.

${ }^{43}$ Ibid. at para 10.
} 
public arena where the state was involved, but were not applied in the private sphere. Violence against women taking place in the home did not therefore fall within the ambit of the traditional interpretation of human rights law. For this body of law to have developed to such an extent that the United States, the most powerful nation in the world, has now been held to be in violation of human rights standards for its failure to protect a victim of domestic violence and her children is certainly remarkable in itself.

It must also be noted that the decision in Lenahan is one of a number of very recent developments in this area. In the European context, the adoption by the Committee of Ministers of the Council of Europe of the Convention on Preventing and Combating Violence against Women and Domestic Violence in April 2011 is undoubtedly significant. The Convention was opened for signature in Istanbul on 11 May 2011 and was signed by 13 states. The provisions of the Convention are comprehensive in nature, encompassing not only criminal justice responses, but also areas such as awareness raising and the provision of social support measures to victims. Likewise, on 15 September 2011 the European Court of Justice issued its judgment in Magatte Gueye and Valentin Salmeron Sanchez, ${ }^{44}$ a case relating to the extent to which the views of victims of domestic violence should be taken into account in criminal justice proceedings against their abusers. Although the European Court of Justice ultimately decided that the human rights issues raised did not fall within its ambit, nevertheless the case raises some very interesting questions regarding the application of human rights law to this area.

The Inter-American Commission on Human Rights is certainly to be commended for its decision in the Lenahan case. The judgment gives further weight to the principle that the failure of a state to provide sufficient protection to victims of domestic violence constitutes a clear violation of human rights standards. It will certainly prove interesting to observe the response of the United States to this decision.

\footnotetext{
${ }^{44}$ Joined Cases C-483/09 and C-1/10 (15 September 2011).
} 